\title{
Decoding the genetic basis of Cushing's disease: USP8 in the spotlight
}

\section{Marily Theodoropoulou, Martin Reincke', Martin Fassnacht ${ }^{2}$ and Masayuki Komada ${ }^{3}$}

Department of Endocrinology, Max Planck Institute of Psychiatry, Kraepelinstrasse 10, Munich 80804, Germany ${ }^{1}$ Medizinische Klinik und Poliklinik IV, Ludwig-Maximilians-Universität München, Munich, Germany,

${ }^{2}$ Endocrine and Diabetes Unit, Department of Medicine I, University Hospital, University of Würzburg, Würzburg, Germany and ${ }^{3}$ Department of Biological Sciences, Tokyo Institute of Technology, 4259-B16 Nagatsuta, Midori, Yokohama 226-8501, Japan
Correspondence

should be addressed

to $\mathrm{M}$ Theodoropoulou

or M Komada

Emails

marily@mpipsykl.mpg.de or makomada@bio.titech.ac.jp

\begin{abstract}
Cushing's disease (CD) arises from pituitary-dependent glucocorticoid excess due to an ACTH-secreting corticotroph tumor. Genetic hits in oncogenes and tumor suppressor genes that afflict other pituitary tumor subtypes are not found in corticotrophinomas. Recently, a somatic mutational hotspot was found in up to half of corticotrophinomas in the USP8 gene that encodes a protein that impairs the downregulation of the epidermal growth factor receptor (EGFR) and enables its constitutive signaling. EGF is an important regulator of corticotroph function and its receptor is highly expressed in Cushing's pituitary tumors, where it leads to increased ACTH synthesis in vitro and in vivo. The mutational hotspot found in corticotrophinomas hyper-activates USP8, enabling it to rescue EGFR from lysosomal degradation and ensure its stimulatory signaling. This review presents new developments in the study of the genetics of CD and focuses on the USP8-EGFR system as trigger and target of corticotroph tumorigenesis.
\end{abstract}

\section{Introduction}

Chronic elevation of adrenocorticotropin (ACTH) concentrations released from corticotroph adenomas leads to Cushing's disease (CD). Its phenotypic features are recent weight gain, central obesity, skin changes, myopathy, disturbed mood and impaired reproductive function, among others. Untreated CD is associated with adverse outcomes. If left untreated, patients die from infections and cardiovascular consequences of glucocorticoid excess (1). The morphologic basis of CD is corticotroph adenoma consisting of basophil cells expressing immunohistochemically ACTH and other POMC-derived peptides (2). Corticotroph adenomas are usually small, and only

Invited Authors' profiles

Marily Theodoropoulou, $\mathrm{PhD}$, is a principal investigator at the Max Planck Institute of Psychiatry, Munich, Germany. Her research focuses on the mechanisms of pituitary tumor formation and pathophysiology and the challenges of identifying novel treatment targets for the optimal management of patients with pituitary adenomas.

Masayuki Komada is a professor in the Department of Biological Sciences at Tokyo Institute of Technology (Tokyo Tech), Japan. Professor Komada is a cell biologist, exploring how cell proliferation is regulated by ubiquitinationdependent growth factor receptor downregulation and how its impairment leads to human tumors. Currently, his laboratory is focusing on the molecular mechanisms by which somatic hotspot mutations in a specific deubiquitinating enzyme cause corticotroph tumorigenesis resulting in Cushing's disease.

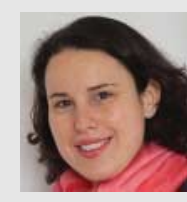

(c) 2015 European Society of Endocrinology Printed in Great Britain Published by Bioscientifica Ltd.
This article is adapted from work presented at IMPROCUSH-1, 12-14 October 2014. The meeting was supported by the European Science Foundation, Deutsche Forschungsgemeinschaft, Carl Friedrich von Siemens Stiftung, European Neuroendocrine Association and the Deutsche Geselischaft furt Endokrinologite. The oppinions or views expressed in this article are those of the authors, and do not necessarily reflecte access the opinions or recommendations of the supporters of the symposium. 
10-20\% of tumors represent macroadenomas (3). The typical patient with $\mathrm{CD}$ is female (female-to-male ratio 3-5:1) and 20-60 years of age (4). The vast majority of corticotroph adenomas appear to be sporadic: patients with $\mathrm{CD}$ do not usually have family history of the disease, making disease-causing germline mutations unlikely. Corticotroph adenomas are typically isolated tumors consisting of a monoclonal cell population in a pituitary of normal size $(5,6,7)$. Selective transsphenoidal adenomectomy causes remission in $60-96 \%$ of patients $(8,9)$.

\section{Genetic events in CD}

The genetic causes underlying corticotroph tumorigenesis have remained obscure until recently (10). Mutations in proto-oncogenes like KRAS, RET, PTTG and $c-M Y C$ and in tumor suppressors like $R B 1$ are very rarely reported in corticotrophinomas (10). Mutations in the p53 gene (TP53) are extremely rare and were found only in atypical corticotroph (i.e., aggressive) tumors and carcinomas (11, 12). CD is rarely seen in the context of genetic syndromes like multiple endocrine neoplasia MEN1 (MEN1 encoding menin), MEN4 (CDKN1B encoding p27/KIP1), McCuneAlbright syndrome (GNAS oncogene encoding the stimulatory $G$ protein $G s \alpha$ ) and never in Carney complex (PRKAR1A) $(13,14,15)$. Patients with McCune-Albright and Carney complex suffer from Cushing's syndrome due to adrenal hyperplasia rather than $\mathrm{CD}$. One case of corticotrophinoma with GNAS mutation was described in a patient with McCune-Albright syndrome (16). A $C D K N 1 B$ variant has been observed in corticotrophinomas in a large cohort of sporadic pituitary adenomas (17). Similarly, CD is rarely found in the context of familial isolated pituitary adenomas (FIPA) that describes the familial occurrence of isolated pituitary adenomas caused by germline aryl hydrocarbon receptor interacting protein (AIP) gene mutations in $20 \%$ of cases (18). From a cohort of 74 pediatric patients with isolated $\mathrm{CD}$, one presented with $A I P$ and two with MEN1 mutations (14). Altogether, mutations in MEN1, AIP, CDKN1B or CDKN2C (encoding $\mathrm{p} 18 / \mathrm{INK} 4 \mathrm{C})$ are rarely found in patients with CD $(14,15$, $19,20)$. These features point to evidence against inheritance caused by germline mutations and suggest an acquired genetic basis of CD.

CD was featured in an adult and in a pediatric patient with tuberous sclerosis, suggesting a putative role for TSC1 and TSC2 in pituitary tumorigenesis $(21,22)$. An ACTHsecreting pituitary adenoma was identified in a patient with X-linked congenital adrenal hypoplasia and mutation in the X-linked NROB1 gene encoding DAX-1 (dosage-sensitive sex reversal, adrenal hypoplasia critical region, on chromosome $X$, gene 1) (23). Mutations in the DICER1 gene encoding the ribonuclease type III that cleaves pre-microRNA to microRNA were found in pituitary blastomas causing infantile CD $(24,25)$. Mutations in the glucocorticoid receptor gene were described in one patient with $\mathrm{CD}$ and resistance to glucocorticoids and in one with Nelson's syndrome (26, 27). Recently, a somatic mutational hotspot was found in the gene encoding ubiquitin-specific protease 8 (USP8) in 30-60\% of sporadic corticotrophinomas $(28,29)$. The USP8 protein product controls the lysosomal trafficking and abundance of cell surface receptors, such as the epidermal growth factor receptor (EGFR), and enables their signaling $(30,31)$.

\section{The EGFR system in CD}

EGF is a prototype growth factor identified by its effect on precocious eyelid opening in newborn mice (32). Soon it became evident that EGF is a potent mitogen that enhances DNA and protein synthesis and shifts metabolic activity in epithelial cells, although it does not have cell-transforming capacity per se (33). EGF induces phosphorylation events in plasma membranes and its receptor was identified as a cellular homologue of the v-erbB oncogene and was found to possess intrinsic tyrosine kinase activity and an ability to undergo autophosphorylation. EGFR internalization has always been linked to its mitogenic potential (reviewed in (33)). Meanwhile, experiments in rat pituitary cells demonstrated that EGF does not always elicit a mitogenic response but can nevertheless alter cell function and response to hormonal signals, revealing a dissociation between the mitogenic and cell differentiation properties (34). EGF was found in the pituitary gland, together with other growth factors, where it acts in an autocrine/paracrine fashion to regulate hormone secretion and cell proliferation (reviewed in (35)). The following section will focus on the expression profile and role of EGF and its receptor in ACTH-producing corticotroph cells.

\section{EGF-EGFR in normal pituitary}

EGF-like activity was detected in the secretome of bovine pituitary cell cultures and EGF expression was identified in the mouse and human anterior pituitary gland by in situ hybridization and immunohistochemistry. Combined in situ hybridization and immunohistochemistry showed Egf mRNA mainly in pituitary somatotrophs $(36,37)$. 
Egf mRNA was also detected in gonadotrophs, and after cold stress in corticotrophs and thyrotrophs (36). In human pituitary gland autopsies, EGF was present in the majority of endocrine cells on the anterior pituitary as determined by immunohistochemistry (38). EGF immunoreactivity was prominent in the cytoplasm of the basophilic cells that infiltrate the posterior pituitary lobe and are ACTH immunopositive, and in Crooke cells associated with corticotrophinomas; the majority of EGF-immunopositive cells stained for ACTH (39).

EGF binding sites were detected on the anterior pituitary by autoradiography on cells that were diagnosed as somatotrophs and lactotrophs based on morphology visualized by electron microscopy (40). A MAB against the intracellular domain (E3138) revealed EGFR expression in corticotrophs as well as in other pituitary cell subpopulations (36). In human pituitary autopsies, EGFR immunoreactivity was mainly detected in corticotrophs and lactotrophs using antibodies directed against the intracellular (clone F4) and extracellular (clone E30) domains $(39,41)$.

\section{EGF-EGFR in pituitary tumors}

In pituitary tumors, initial studies linked EGF with nonfunctioning pituitary adenomas, based on secretion and immunohistochemistry $(35,42)$. However, it soon became evident that EGF is present in human corticotrophinomas and tends to correlate with invasiveness $(39,43)$. EGF binding was detected in pituitary tumors, despite the initial negative autoradiography results $(41,44,45)$. Semiquantitative reverse transcriptase PCR analysis and northern blot showed EGFR transcript in representatives of all pituitary tumor types, including all the assayed corticotrophinomas $(38,41)$. In contrast, all tumors were negative for the constitutive active truncated EGFR variant III (41). Initial immunohistochemical analysis revealed EGF and its receptor, as detected by two MABs against the cytoplasmatic (clone F4) and extracellular (clone 29.1) EGFR domains, mainly in the majority of the nonfunctioning pituitary adenomas in a set of 54 pituitary adenomas (42). Use of another MAB against the extracellular receptor domain (MU 207/clone E30) showed EGFR expression in representatives from all pituitary tumor types in a series of 28 pituitary tumors (38) and in most corticotrophinomas in a series of 72 paraffinembedded pituitary tumors (41). The different results obtained with the two MABs recognizing the extracellular EGFR domain may be due to the fact that the clone 29.1 antibody cross-reacts with glycosidic factors, possibly because it was raised against the carbohydrate epitope of EGFR. The predominance of EGFR in corticotrophinomas became evident through two independent studies on large series of pituitary adenomas ( $n=58$ and $n=102)$ using the clone F4 antibody $(39,41)$. In both studies, immunopositive corticotrophinomas expressed EGFR in 50\% of their endocrine cells. Differences in the sample size and in the immunohistochemistry and antigen retrieval protocols may explain the differences in the findings using the clone F4 antibody between the first (42) and the two subsequent studies $(39,41)$. All EGFR-expressing corticotrophinomas showed immunoreactivity for the phosphorylated EGFR at tyrosine 992, indicative of activated receptor, a phenomenon that tended to be corticotrophinoma-specific as it was not observed in the majority of EGFR-immunopositive acromegalic tumors (41).

\section{EGFR and corticotroph function}

The role of EGF on the regulation of ACTH synthesis was already suspected in the 1980 s by observing a crosstalk with hypothalamic-pituitary-adrenal axis in vivo. EGF was as potent as $\mathrm{CRH}$ in triggering ACTH secretion in vivo and this was not accompanied by increased CRH and/or AVP, indicating a direct pituitary effect (46). A parallel study in monkeys demonstrated that EGF-induced ACTH was due to increased $\mathrm{CRH}$, an action hypothesized to take place on sites outside the blood brain barrier since it cannot be crossed by EGF (47). The direct action of EGF on corticotrophs was confirmed by the increased number of cells expressing POMC and ACTH secretion from both mixed and (corticotroph)-enriched cultures, indicating that the presence of other pituitary cell populations does not interfere with its action (48). Furthermore, EGF increased BrdU uptake (indicative of replicating cells) in ACTH enriched dispersed anterior pituitary cells $(48,49)$. In primary cultures of male mouse anterior pituitaries, EGF treatment enhanced BrdU uptake in ACTH- (as well as in PRL-) immunopositive cells, but not in other pituitary cell subpopulations (37). The EGFR inhibitor RG-13022 decreased the percentage of BrdU labeled cells immunoreactive for ACTH (and PRL), providing functional evidence for the presence of active receptors on corticotroph (and lactotroph) populations (50).

EGF treatment increased Pomc transcription and ACTH secretion in EGFR-overexpressing corticotrophinoma cells and in corticotroph tumors from dogs and human patients with CD (51). EGFR overexpression in the mouse corticotrophinoma AtT-20 cells (that do not express the receptor) triggered basal Pomc transcription 
(28). All these effects were mediated through Erk1/2 and acted on the proximal to initiation site of the Pomc promoter $(28,51)$. Treatment with the EGFR tyrosine kinase inhibitor gefitinib decreased ACTH synthesis and secretion in human corticotrophinomas in vitro and decreased tumor growth and corticosterone levels in a xenograft corticotroph tumor animal model, where it ameliorated the symptoms of CD (51).

In corticotrophinomas, EGFR immunoreactivity correlated with EGF (39), suggesting a possible autocrine regulatory loop. This is indicated by the presence of immunoreactivity for the phosphorylated, i.e., activated, receptor in these tumors $(41,52)$. EGFR-expressing corticotrophinomas also had very weak or absent immunoreactivity for the cell cycle inhibitor p27 (41). This is of interest, since loss of p27 protein (but not transcript) is a prominent feature of human corticotrophinomas $(53,54)$. One hypothesis is that activated EGFR triggers signaling cascades that downregulate p27 in corticotrophinomas, which in addition to the stimulatory action on ACTH synthesis contributes to their tumorigenesis.

\section{Somatic USP8 mutations in CD}

\section{Regulation of EGFR downregulation by ubiquitination and deubiquitination}

Ubiquitin is a 76-amino-acid protein that is highly conserved in eukaryotes. Ubiquitin is conjugated, via the C-terminal carboxyl group, to the $\varepsilon$-amino group of Lys residues in various proteins in the cell by an isopeptide bond (55). Additional ubiquitin molecules are further conjugated to the already-conjugated ubiquitins sequentially, leading to the formation of polyubiquitin chains on the substrate proteins. This post-translational modification, referred to as ubiquitination, is catalyzed by sequential actions of three enzymes: ubiquitin-activating enzyme (E1), ubiquitin-conjugating enzyme (E2) and ubiquitin ligase (E3). Approximately 500 E3 enzymes, each of which is considered to ubiquitinate specific substrate proteins, are encoded in the human genome (56). Ubiquitination regulates the fates or functions of the substrate proteins in multiple ways: it participates in protein degradation in the proteasome, DNA repair, endocytosis and lysosomal trafficking, NFKB signaling and so on (57). Like protein phosphorylation, which is reversed by phosphatases, ubiquitination is a reversible reaction opposed by a family of deubiquitinases (DUBs) that remove the ubiquitin moiety from substrate proteins by hydrolyzing the isopeptide bond between them (58).
The human genome encodes $\sim 90$ DUBs (59). The numbers of human E3 enzymes ( 500) and DUBs ( 90$)$ suggest that the functions of many intracellular proteins are regulated by a balance of ubiquitination and deubiquitination.

For plasma membrane proteins, ubiquitination serves as a signal that delivers the protein from the cell surface to lysosomes $(60,61,62)$. In mammalian cells, such a role of ubiquitination has most intensively been studied for EGFR. Upon EGF binding on the cell surface, activated EGFR is rapidly internalized and transported, via early and late endosomes, to lysosomes where EGFR is degraded by proteolytic hydrolases. This process, referred to as receptor downregulation, is a cellular strategy to prevent the cells from responding excessively to EGF due to sustained signals from activated EGFR (63). An E3 enzyme c-Cbl is recruited to ligand-activated EGFR and ubiquitinates the receptor, adding a tag that targets activated EGFR to lysosomes for degradation $(64,65)$. We and others have previously shown that USP8, also known as UBPY, is a DUB that deubiquitinates EGFR on early endosomes, thereby removing the lysosome-targeting tag and suppressing its downregulation $(30,66)$. Vertebrate USP8 proteins have a conserved 14-3-3 protein-binding motif (14-3-3 BM), RSYSSP (Fig. 1). 14-3-3 proteins, composed of seven isoforms in humans, are regulatory proteins that bind to a consensus amino acid sequence, RSXpSXP, where $\mathrm{X}$ and pS represent any amino acid and phosphorylated Ser respectively and thereby regulate the functions (e.g., subcellular localization and enzymatic activity) of various 14-3-3 BM-bearing intracellular proteins (67). We have demonstrated that the binding of 14-3-3 proteins to the 14-3-3 BM of mouse USP8 suppresses its DUB activity toward ubiquitinated EGFR (68), although how 14-3-3 protein binding regulates USP8 activity has remained unknown until recently.

\section{Hotspot mutations in USP8 in corticotrophinomas}

To elucidate the molecular mechanisms underlying the pathogenesis of $\mathrm{CD}$, whole exome analyses of corticotrophinomas removed from pituitaries of the $\mathrm{CD}$ patients were performed $(28,29)$. As a result, 19 different mutations were identified in or adjacent to the 14-3-3 BM of USP8, and replicated by targeted sequencing, in 35\% (six out of 17) (27) and $62.5 \%$ (75 out of 120) (29) of corticotrophinomas (Fig. 1). Both the mutant and WT USP8 sequences were detected in the adenoma DNA samples, and the mutations were not detected in the germline of the patients, suggesting that they are somatic heterozygous mutations. 


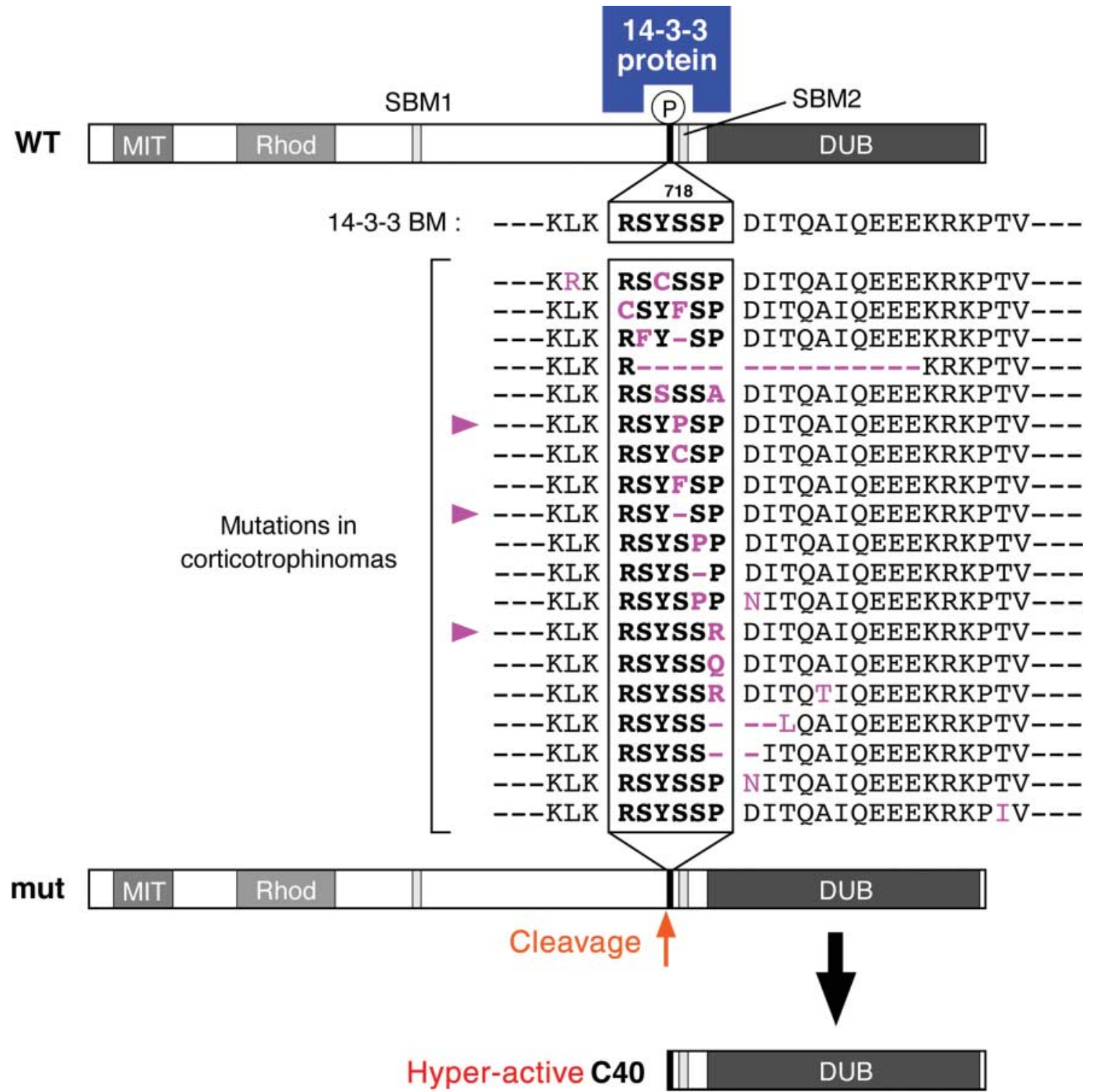

\section{Figure 1}

Hotspot gain-of-function mutations in USP8 in corticotrophinomas. In WT human USP8, 14-3-3 proteins bind to the 14-3-3 BM, RSYSSP, when Ser ${ }^{718}$ is phosphorylated. Nineteen hotspot mutations in or around the 14-3-3 BM were recently identified in corticotrophinomas taken from the CD patients $(28,29)$.

Pink arrowheads indicate most frequently identified mutations. The mutations lead to the loss of 14-3-3 protein binding and

Among the USP8 mutants examined, p.Ser718Pro, p.Ser718Cys, p.Ser718del and p.Pro720Arg almost completely lost binding to $14-3-3$ proteins, while the p.[Leu713Arg;Tyr717Cys] mutant retained some 14-3-3 binding ability. When immunopurified USP8 mutants were incubated with ubiquitinated EGFR, mutants except promote USP8 cleavage immediately N-terminal to the 14-3-3 BM (experimentally demonstrated for the p.S718P, p.S718C, p.S718del and p.P720R mutants). The cleaved C-terminal 40-kDa DUB domain (C40) acquires elevated catalytic activity. MIT, microtubule-interacting and trafficking domain; Rhod, rhodanese homology domain; SBM, SH3-binding motif.

for p.[Leu713Arg;Tyr717Cys] exhibited higher DUB activity than WT USP8 (28), consistent with our previous results in mouse USP8 lacking 14-3-3 binding (68).

The level of the elevated DUB activity varied among the USP8 mutants. During the course of the experiments, it was noticed that in addition to the 130-kDa full-length 
form, minor $90-\mathrm{kDa}$ and $40-\mathrm{kDa}$ fragments are present for the p.Ser718Pro, p.Ser718Cys, p.Ser718del and p.Pro720Arg mutants. They were hardly detected in WT USP8 and their levels clearly correlated with the DUB activity of the mutant; mutants with higher levels of the fragments exhibited higher catalytic activity. The fragments were never detected in the p.[Leu713Arg; Tyr717Cys] mutant with similar or even weaker DUB activity than WT USP8. Examination of the tryptic peptides of the 90- and 40-kDa fragments by tandem mass spectrometry determined the C-terminus of the $90-\mathrm{kDa}$ fragment as the Lys residue immediately upstream of the 14-3-3 BM, and the N-terminus of the $40-\mathrm{kDa}$ fragment as the first Arg residue of the 14-3-3 BM, indicating that the USP8 mutants are susceptible to cleavage adjacent to the 14-3-3 BM (Fig. 1). The C-terminal 40-kDa fragment (USP8-C40) harbors the whole catalytic domain and acquires an elevated DUB activity. Introduction of the p.Ser718Pro, p.Ser718Cys, p.Ser718del or p.Pro720Arg mutation into USP8-C40 did not further elevate the catalytic activity, suggesting that the cleavage but not the amino acid replacements/ deletion is responsible for the elevated USP8 activity. Thus, the CD USP8 mutants, except for p.[Leu713Arg;Tyr717Cys], lack 14-3-3 protein binding and are prone to cleavage adjacent to the 14-3-3 BM, resulting in high catalytic activity (28).

\section{The CD USP8 mutants affect EGFR downregulation and ACTH synthesis}

When the p.Ser718del mutant or C40 form of USP8 was overexpressed in cultured cells, the level of EGF-induced EGFR ubiquitination was reduced compared to cells overexpressing WT USP8. Co-immunoprecipitation experiments showed that EGFR from both untreated and EGF-treated cells binds to the WT and p.Ser718del mutant as well as C40 forms of USP8 but not the 90-kDa fragment, indicating that USP8-C40 interacts with and excessively deubiquitinates EGFR in vivo, and supporting the theory that EGFR is a bona fide substrate of USP8-C40 (28).

Examination of EGFR endocytosis in cultured cells expressing the CD mutant or C40 forms of USP8 showed that their overexpression, but not that of WT USP8, causes retention of EGFR on the cell surface after EGF stimulation. A catalytically-inactive mutant of C40 was without effect, indicating that the USP8 mutants inhibit EGFR downregulation in a DUB activity-dependent manner. When recycling of endocytosed EGFR from early endosomes to the plasma membrane was blocked by overexpression of a GDP-fixed mutant of Rab11, a small GTPase required for the recycling pathway (69), EGFR was stuck on Rab11-positive recycling endosomes in C40expressing cells but not in mock-transfected cells or those expressing a catalytically-inactive mutant of C40. In addition, immunofluorescence staining of EGF-treated cells for activated (Thr202- and Tyr204-phosphorylated) Erk1/2 showed that Erk1/2 are still active after $2 \mathrm{~h}$ of EGF treatment in cells overexpressing the CD mutant or C40 forms of USP8. Collectively, these results suggest that the USP8 mutants promote recycling of activated and endocytosed EGFR back to the plasma membrane and cause sustained EGF signaling (28). Consistently, a more recent study showed that the EGFR protein level is elevated in human corticotrophinoma tissues with a USP8 mutation, and the level was decreased in primary culture of USP8mutated corticotrophinomas by RNA interferencemediated depletion of USP8 (29).

The effect of the USP8 mutations on ACTH synthesis and secretion was examined in AtT-20 mouse corticotrophinoma cells. In EGFR-transfected AtT-20 cells, co-expression of the CD mutant or C40 forms but not WT of USP8 further elevated the Pomc promoter activity. Treatment of EGFR-transfected AtT-20 cells with EGF resulted in elevated ACTH secretion from the cells, and overexpression of the CD mutant or C40 forms of USP8 reinforced the effect of EGF. Elevation in the Pomc promoter activity by the CD mutant or C40 forms of USP8 depended on the activator protein-1 (AP1) transcription factor-responsive element in the Pomc gene, which is activated downstream of Erk1/2 ((70); Fig. 2). On the other hand, overexpression of the CD mutant or C40 forms of USP8 did not significantly accelerate the proliferation of EGFR-transfected AtT-20 cells in the presence or absence of EGF compared to that of WT USP8, suggesting that in corticotroph, sustained EGF signaling caused by the USP8 mutations affects ACTH synthesis more profoundly than cell proliferation (28). In primary cultures of USP8mutated human corticotrophinomas, USP8 depletion led to reduced level of ACTH secretion (29).

\section{Another role of the CD USP8 mutants in the nucleus?}

Cytoplasmic localization of hyper-active USP8-C40 suggests that the cytoplasmic DUB activity of USP8 is responsible for the pathogenesis of CD. WT USP8 is also localized to the cytoplasm in normal human corticotrophs. In corticotrophinomas of the CD patients, however, all the USP8 mutants were detected in the nucleus. Consistently, most of the ectopically-expressed 


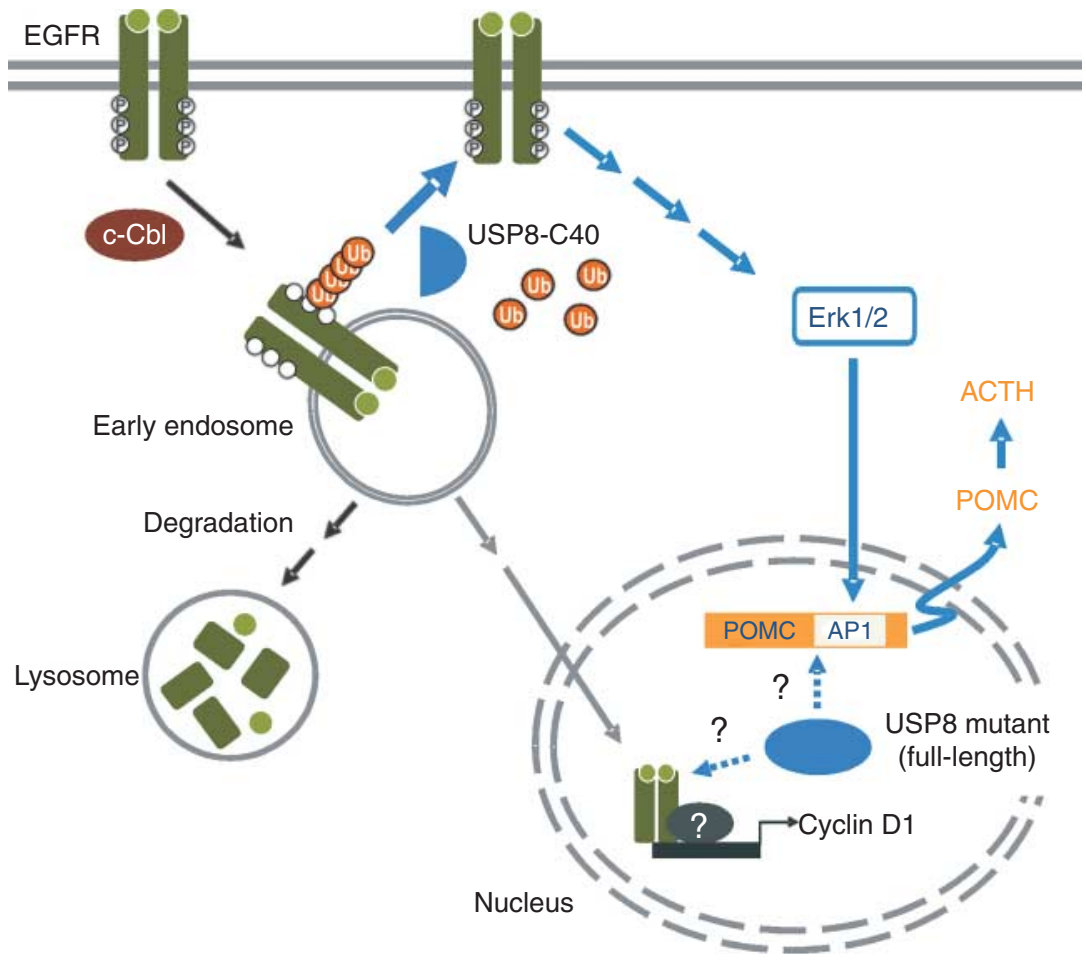

\section{Figure 2}

Schematic presentation of the impact of USP8 mutations on EGFR trafficking and signaling in corticotrophinoma cells. EGF binding to the receptor results in a series of autophosphorylation events. These trigger several signaling cascades, but also recruit $\mathrm{c}-\mathrm{Cbl}$ that ubiquitinates the receptor and marks it for endocytosis to the early endosome and subsequent lysosomal degradation. The cleaved catalytic domain of the USP8 mutants (C40), with its higher DUB activity, effectively deubiquitinates EGFR and promotes its recycling to the plasma membrane, where it activates signaling cascades including the Erk1/2 pathway that phosphorylates transcription factors binding to the AP1 responsive element on the POMC promoter. This leads

USP8 mutants exhibited nuclear localization also in cultured cells. The p.[Leu713Arg;Tyr717Cys] mutant, which is most exclusively localized to the nucleus among the mutants, does not undergo proteolytic activation. These observations raise the possibility that the CD USP8 mutants have a yet-to-be identified nuclear function that has another important role in the pathogenesis of CD.

Interestingly, there is an evidence for nuclear action of EGF. Studies in pituitary tumor cells have shown that EGF accumulates in the nucleus under conditions that inhibit its lysosomal degradation, an effect that was attributed to enhanced POMC transcription and ACTH synthesis. The findings of nuclear localization of EGFR and full-length USP8 mutants (before cleavage) in human corticotrophinomas prompt us to also consider the possibility of nuclear action. EGFR is believed to be translocated from the plasma membrane to the inner nuclear membrane and released into the nucleus (retrograde translocation). The potential mechanism of action and the substrates of USP8 in the corticotrophinoma cell nucleus are at present unclear. P, phosphorylation; Ub, ubiquitin; blue arrows, USP8-induced signaling events; punctuated arrows, hypothetical events.

to the fusion of endocytic vesicles with the outer nuclear membrane (71). EGFR was shown to translocate to the nucleus, where it enhances the transcription of genes involved in cell cycle progression like CCND1 encoding cyclin D1 (72). Cyclin D1 overexpression that is the functional characteristic of nuclear EGFR is not featured in human corticotrophinomas (10). Nevertheless, nuclear EGFR was detected by immunofluorescence in this pituitary tumor subtype (50). Nuclear EGFR deubiquitination by nuclearly-located USP8 mutants may regulate the nuclear function of EGFR. Alternatively, the USP8 mutants might have other nuclear substrate(s), whose 
deubiquitination is responsible for the hypersecretion of ACTH. Transcription factors involved in POMC gene expression are potential candidates for such USP8 substrates.

\section{Implications}

We have recently unveiled a molecular basis for the pathogenesis of $\mathrm{CD}$ in one-third of the patients: gainof-function mutations in the DUB gene USP8 lead to excessive deubiquitination and reduced downregulation of EGFR, which in turn result in sustained EGF signaling and hypersecretion of ACTH (28). These outcomes suggest that inhibiting USP8 activity in corticotrophinomas could be therapeutic to CD. In addition, because the USP8 mutants are hyper-activated by cleavage, inhibiting the cleavage could also be therapeutic to CD. Identification of the protease responsible for the proteolytic activation of USP8, and screening for chemical compounds that inhibit USP8 or the unidentified USP8 protease, are therefore of medical importance for the development of anti-CD drugs. A more recent study confirmed our observation reporting USP8 mutations in 67 of 108 corticotrophinomas (62\%) from Chinese patients (29). Inhibiting EGFR could also be applied to the therapy of CD harboring USP8 mutations because direct inhibition of EGFR by gefitinib in primary cultures of USP8 mutant corticotroph adenomas attenuated ACTH release (29).

Upregulation of EGFR has been implicated in various tumors and cancers (73). However, mutations in the 14-33 BM of USP8 are rarely found in whole genome analyses of such disease tissues (COSMIC database, http://cancer. sanger.ac.uk/cancergenome/projects/cosmic/). Furthermore, a significantly elevated level of cell proliferation is not observed in corticotrophinomas in CD patients, raising the possibility that additional proteins besides EGFR are targeted by USP8. If deubiquitinated and stabilized by USP8 mutations, they may contribute to the pathogenesis of CD. These could be other corticotrophspecific plasma membrane protein(s) acting upstream of POMC gene expression. Because the USP8 mutants exhibit nuclear localization, it is possible that the target could even be a nuclear protein that, for instance, regulates POMC gene expression.

CD patients with corticotrophinomas positive for USP8 mutations (USP8mut +) were more frequently female and had a tendency for smaller tumor size compared to those with USP8 WT tumors (28). The more extended cohort of Ma et al. (29) $(n=120)$ showed comparable ACTH levels, midnight serum cortisol and 24-h urinary free cortisol in patients with USP8mut + and WT corticotrophinomas, despite the smaller size of USP8mut + tumors. This together with the increased levels of tumor POMC transcript in the USP8mut+ tumors suggests ACTH hypersecretion. Further studies are needed to address in detail the clinical impact of USP8 mutations in CD presentation and management. In addition, information is missing on the role of USP8 mutational status in the development of resistance to glucocorticoid feedback inhibition, a hallmark of CD. Glucocorticoid resistance is mainly due to deregulated glucocorticoid receptor transrepression regulation and chaperon proteins, but the responsible genetic defects remain for the most part unclear $(74,75)$. Altogether, the finding in CD tumors of a single mutational hotspot on the USP8 gene that encodes for an important regulator of protein stability and function serves as a focal point for the better understanding of corticotroph tumor development and the development of effective tumor-targeted therapies.

Declaration of interest

The authors declare that there is no conflict of interest that could be perceived as prejudicing the impartiality of the review.

\section{Funding}

The Symposion was sponsored by scientific unrestricted grants of the DFG (Re 752/22-1), the European Science Foundation (Ref. Number: 5551) and by the Carl Friedrich von Siemens Stiftung. M Reincke is supported by a grant from the Else Kröner-Fresenius Stiftung to (2012_A103). $\mathrm{M}$ Theodoropoulou, M Fassnacht and M Komada have nothing to disclose.

\begin{abstract}
Acknowledgements
This paper forms part of a special issue of European Journal of Endocrinology on Cushing's syndrome. This article is adapted from work presented at the IMPROCUSH-1: Improving Outcome of Cushing's Syndrome symposium, 12-14 October 2014. The meeting was supported by the European Science Foundation, Deutsche Forschungsgemeinschaft, Carl Friedrich von Siemens Stiftung, European Neuroendocrine Association and the Deutsche Gesellschaft für Endokrinologie. The opinions or views expressed in this special issue are those of the authors, and do not necessarily reflect the opinions or recommendations of the European Science Foundation, Deutsche Forschungsgemeinschaft, Carl Friedrich von Siemens Stiftung, European Neuroendocrine Association and the Deutsche Gesellschaft fur Endokrinologie.
\end{abstract}

\section{References}

1 Tritos NA \& Biller BM. Cushing's disease. Handbook of Clinical Neurology 2014124 221-234. (doi:10.1016/B978-0-444-59602-4.00015-0)

2 Saeger W. Surgical pathology of the pituitary in Cushing's disease. Pathology, Research and Practice 1991187 613-616. (doi:10.1016/S03440338(11)80156-1) 
3 Hofmann BM, Hlavac M, Martinez R, Buchfelder M, Müller OA \& Fahlbusch R. Long-term results after microsurgery for Cushing disease: experience with 426 primary operations over 35 years. Journal of Neurosurgery 2008108 9-18. (doi:10.3171/JNS/2008/108/01/0009)

4 Valassi E, Santos A, Yaneva M, Tóth M, Strasburger CJ, Chanson P, Wass JA, Chabre O, Pfeifer M, Feelders RA etal. The European Registry on Cushing's syndrome: 2-year experience. Baseline demographic and clinical characteristics. European Journal of Endocrinology/European Federation of Endocrine Societies 2011165 383-392. (doi:10.1530/EJE-11-0272)

5 Schulte HM, Oldfield EH, Allolio B, Katz DA, Berkman RA \& Ali IU. Clonal composition of pituitary adenomas in patients with Cushing's disease: determination by X-chromosome inactivation analysis. Journal of Clinical Endocrinology and Metabolism 199173 1302-1308. (doi:10.1210/jcem-73-6-1302)

6 Gicquel C, Le Bouc Y, Luton JP, Girard F \& Bertagna X. Monoclonality of corticotroph macroadenomas in Cushing's disease. Journal of Clinical Endocrinology and Metabolism 199275 472-475. (doi:10.1210/jcem.75. 2.1322426))

7 Biller BM, Alexander JM, Zervas NT, Hedley-Whyte ET, Arnold A \& Klibanski A. Clonal origins of adrenocorticotropin-secreting pituitary tissue in Cushing's disease. Journal of Clinical Endocrinology and Metabolism 199275 1303-1309. (doi:10.1210/jcem.75.5.1358909))

8 Dimopoulou C, Schopohl J, Rachinger W, Buchfelder M, Honegger J, Reincke M \& Stalla GK. Long-term remission and recurrence rates after first and second transsphenoidal surgery for Cushing's disease: care reality in the Munich Metropolitan Region. European Journal of Endocrinology/European Federation of Endocrine Societies 2013170 283-292. (doi:10.1530/EJE-13-0634)

9 Petersenn S, Beckers A, Ferone D, van der Lely A, Bollerslev J, Boscaro M, Brue T, Bruzzi P, Casanueva F, Chanson P et al. Therapy of Endocrine Disease: Outcomes in patients with Cushing's disease undergoing transsphenoidal surgery: systematic review assessing criteria used to define remission and recurrence. European Journal of Endocrinology 2015 172 R227-R239. (doi:10.1530/EJE-14-0883)

10 Dworakowska D \& Grossman AB. The molecular pathogenesis of corticotroph tumours. European Journal of Clinical Investigation 201242 665-676. (doi:10.1111/j.1365-2362.2011.02621.x)

11 Kawashima ST, Usui T, Sano T, Iogawa H, Hagiwara H, Tamanaha T, Tagami T, Naruse M, Hojo M, Takahashi JA et al. P53 gene mutation in an atypical corticotroph adenoma with Cushing's disease. Clinical Endocrinology 200970 656-657. (doi:10.1111/j.1365-2265.2008.03404.x)

12 Tanizaki Y, Jin L, Scheithauer BW, Kovacs K, Roncaroli F \& Lloyd RV. P53 gene mutations in pituitary carcinomas. Endocrine Pathology 2007 18 217-222. (doi:10.1007/s12022-007-9006-y)

13 Matsuzaki LN, Canto-Costa MH \& Hauache OM. Cushing's disease as the first clinical manifestation of multiple endocrine neoplasia type 1 (MEN1) associated with an R460X mutation of the MEN1 gene. Clinical Endocrinology 200460 142-143. (doi:10.1111/j.1365-2265.2004.01943.x)

14 Stratakis CA, Tichomirowa MA, Boikos S, Azevedo MF, Lodish M, Martari M, Verma S, Daly AF, Raygada M, Keil MF et al. The role of germline AIP, MEN1, PRKAR1A, CDKN1B and CDKN2C mutations in causing pituitary adenomas in a large cohort of children, adolescents, and patients with genetic syndromes. Clinical Genetics $2010 \mathbf{7 8}$ 457-463. (doi:10.1111/j.1399-0004.2010.01406.x)

15 Tichomirowa MA, Lee M, Barlier A, Daly AF, Marinoni I, JaffrainRea ML, Naves LA, Rodien P, Rohmer V, Faucz FR et al. Cyclindependent kinase inhibitor 1B (CDKN1B) gene variants in AIP mutation-negative familial isolated pituitary adenoma kindreds. Endocrine-Related Cancer 201219 233-241. (doi:10.1530/ERC-11-0362)

16 Riminucci M, Collins MT, Lala R, Corsi A, Matarazzo P, Gehron Robey P $\&$ Bianco P. An R201H activating mutation of the GNAS1 (Gs $\alpha$ ) gene in a corticotroph pituitary adenoma. Molecular Pathology 200255 58-60. (doi:10.1136/mp.55.1.58)

17 Sekiya T, Bronstein MD, Benfini K, Longuini VC, Jallad RS, Machado MC, Goncalves TD, Osaki LH, Higashi L, Viana-Jr J et al. p27 variant and corticotropinoma susceptibility: a genetic and in vitro study. Endocrine-Related Cancer 201421 395-404. (doi:10.1530/ ERC-13-0486)

18 Daly AF, Vanbellinghen JF, Khoo SK, Jaffrain-Rea ML, Naves LA, Guitelman MA, Murat A, Emy P, Gimenez-Roqueplo AP, Tamburrano G et al. Aryl hydrocarbon receptor-interacting protein gene mutations in familial isolated pituitary adenomas: analysis in 73 families. Journal of Clinical Endocrinology and Metabolism 200792 1891-1896. (doi:10.1210/jc.2006-2513)

19 Georgitsi M, Raitila A, Karhu A, Tuppurainen K, Mäkinen MJ, Vierimaa O, Paschke R, Saeger W, van der Luijt RB, Sane T et al. Molecular diagnosis of pituitary adenoma predisposition caused by aryl hydrocarbon receptor-interacting protein gene mutations. PNAS 2007 104 4101-4105. (doi:10.1073/pnas.0700004104)

20 Tichomirowa MA, Barlier A, Daly AF, Jaffrain-Rea ML, Ronchi C, Yaneva M, Urban JD, Petrossians P, Elenkova A, Tabarin A et al. High prevalence of AIP gene mutations following focused screening in young patients with sporadic pituitary macroadenomas. European Journal of Endocrinology 2011165 509-515. (doi:10.1530/EJE-11-0304)

21 Tigas S, Carroll PV, Jones R, Bingham E, Russell-Jones D, Powell M \& Scobie IN. Simultaneous Cushing's disease and tuberous sclerosis; a potential role for TSC in pituitary ontogeny. Clinical Endocrinology 2005 63 694-695. (doi:10.1111/j.1365-2265.2005.02374.x)

22 Nandagopal R, Vortmeyer A, Oldfield EH, Keil MF \& Stratakis CA. Cushing's syndrome due to a pituitary corticotropinoma in a child with tuberous sclerosis: an association or a coincidence? Clinical Endocrinology 200767 639-641. (doi:10.1111/j.1365-2265.2007.02941.x)

23 De Menis E, Roncaroli F, Calvari V, Chiarini V, Pauletto P, Camerino G $\&$ Cremonini N. Corticotroph adenoma of the pituitary in a patient with X-linked adrenal hypoplasia congenita due to a novel mutation of the DAX-1 gene. European Journal of Endocrinology 2005153 211-215. (doi:10.1530/eje.1.01958)

24 Sahakitrungruang T, Srichomthong C, Pornkunwilai S, Amornfa J, Shuangshoti S, Kulawonganunchai S, Suphapeetiporn K \& Shotelersuk V. Germline and somatic DICER1 mutations in a pituitary blastoma causing infantile-onset Cushing's disease. Journal of Clinical Endocrinology and Metabolism 201499 E1487-E1492. (doi:10.1210/ jc.2014-1016)

25 de Kock L, Sabbaghian N, Plourde F, Srivastava A, Weber E, Bouron-Dal Soglio D, Hamel N, Choi JH, Park SH, Deal CL et al. Pituitary blastoma: a pathognomonic feature of germ-line DICER1 mutations. Acta Neuropathologica 2014128 111-122. (doi:10.1007/s00401-014-1285-z)

26 Karl M, Lamberts SW, Koper JW, Katz DA, Huizenga NE, Kino T, Haddad BR, Hughes MR \& Chrousos GP. Cushing's disease preceded by generalized glucocorticoid resistance: clinical consequences of a novel, dominant-negative glucocorticoid receptor mutation. Proceedings of the Association of American Physicians 1996108 296-307.

27 Karl M, Von Wichert G, Kempter E, Katz DA, Reincke M, Mönig H, Ali IU, Stratakis CA, Oldfield EH, Chrousos GP et al. Nelson's syndrome associated with a somatic frame shift mutation in the glucocorticoid receptor gene. Journal of Clinical Endocrinology and Metabolism $1996 \mathbf{8 1}$ 124-129. (doi:10.1210/jcem.81.1.8550738)

28 Reincke M, Sbiera S, Hayakawa A, Theodoropoulou M, Osswald A, Beuschlein F, Meitinger T, Mizuno-Yamasaki E, Kawaguchi K, Saeki Y et al. Mutations in the deubiquitinase gene USP8 cause Cushing's disease. Nature Genetics 201547 31-38. (doi:10.1038/ng.3166)

29 Ma ZY, Song ZJ, Chen JH, Wang YF, Li SQ, Zhou LF, Mao Y, Li YM, $\mathrm{Hu}$ RG, Zhang ZY et al. Recurrent gain-of-function USP8 mutations in Cushing's disease. Cell Research 201525 306-317. (doi:10.1038/cr. 2015.20)

30 Mizuno E, Iura T, Mukai A, Yoshimori T, Kitamura N \& Komada M. Regulation of epidermal growth factor receptor down-regulation by UBPY-mediated deubiquitination at endosomes. Molecular Biology of the Cell 200516 5163-5174. (doi:10.1091/mbc.E05-06-0560)

31 Mukai A, Yamamoto-Hino M, Awano W, Watanabe W, Komada M \& Goto S. Balanced ubiquitylation and deubiquitylation of Frizzled 
regulate cellular responsiveness to Wg/Wnt. Embo Journal 201029 2114-2125. (doi:10.1038/emboj.2010.100)

32 Cohen S. Isolation of a mouse submaxillary gland protein accelerating incisor eruption and eyelid opening in the new-born animal. Journal of Biological Chemistry 1962237 1555-1562.

33 Carpenter G \& Cohen S. Epidermal growth factor. Annual Review of Biochemistry 197948 193-216. (doi:10.1146/annurev.bi.48.070179. 001205)

34 Johnson LK, Baxter JD, Vlodavsky I \& Gospodarowicz D. Epidermal growth factor and expression of specific genes: effects on cultured rat pituitary cells are dissociable from the mitogenic response. PNAS 1980 77 394-398. (doi:10.1073/pnas.77.1.394)

35 Renner U, Pagotto U, Arzt E \& Stalla GK. Autocrine and paracrine roles of polypeptide growth factors, cytokines and vasogenic substances in normal and tumorous pituitary function and growth: a review. European Journal of Endocrinology/European Federation of Endocrine Societies 1996135 515-532. (doi:10.1530/eje.0.1350515)

36 Fan X \& Childs GV. Epidermal growth factor and transforming growth factor- $\alpha$ messenger ribonucleic acids and their receptors in the rat anterior pituitary: localization and regulation. Endocrinology 1995136 2284-2293.

37 Honda J, Oomizu S, Kiuchi Y, Komatsu N, Takeuchi S \& Takahashi S. Identification of epidermal growth factor mRNA-expressing cells in the mouse anterior pituitary. Neuroendocrinology 200071 155-162. (doi:10.1159/000054532)

38 LeRiche VK, Asa SL \& Ezzat S. Epidermal growth factor and its receptor (EGF-R) in human pituitary adenomas: EGF-R correlates with tumor aggressiveness. Journal of Clinical Endocrinology and Metabolism $1996 \mathbf{8 1}$ 656-662. (doi:10.1210/jcem.81.2.8636285)

39 Kontogeorgos G, Stefaneanu L, Kovacs K \& Cheng Z. Localization of epidermal growth factor (EGF) and epidermal growth factor receptor (EGFr) in human pituitary adenomas and nontumorous pituitaries: an immunocytochemical study. Endocrine Pathology 19967 63-70. (doi:10.1007/BF02739916)

40 Chabot JG, Walker P \& Pelletier G. Distribution of epidermal growth factor binding sites in the adult rat anterior pituitary gland. Peptides 19867 45-50. (doi:10.1016/0196-9781(86)90059-8)

41 Theodoropoulou M, Arzberger T, Gruebler Y, Jaffrain-Rea ML, Schlegel J, Schaaf L, Petrangeli E, Losa M, Stalla GK \& Pagotto U. Expression of epidermal growth factor receptor in neoplastic pituitary cells: evidence for a role in corticotropinoma cells. Journal of Endocrinology 2004183 385-394. (doi:10.1677/joe.1.05616)

42 Chaidarun SS, Eggo MC, Sheppard MC \& Stewart PM. Expression of epidermal growth factor (EGF), its receptor, and related oncoprotein (erbB-2) in human pituitary tumors and response to EGF in vitro. Endocrinology 1994135 2012-2021. (doi:10.1210/endo.135.5.7956924)

43 Lubke D, Saeger W \& Ludecke DK. Proliferation markers and EGF in ACTH-secreting adenomas and carcinomas of the pituitary. Endocrine Pathology 19956 45-55. (doi:10.1007/BF02914988)

44 Birman P, Michard M, Li JY, Peillon F \& Bression D. Epidermal growth factor-binding sites, present in normal human and rat pituitaries, are absent in human pituitary adenomas. Journal of Clinical Endocrinology and Metabolism 198765 275-281. (doi:10.1210/jcem-65-2-275)

45 Jaffrain-Rea ML, Petrangeli E, Lubrano C, Minniti G, Di Stefano D, Sciarra F, Frati L, Tamburrano G, Cantore G \& Gulino A. Epidermal growth factor binding sites in human pituitary macroadenomas. Journal of Endocrinology 1998158 425-433. (doi:10.1677/joe.0.1580425)

46 Polk DH, Ervin MG, Padbury JF, Lam RW, Reviczky AL \& Fisher DA. Epidermal growth factor acts as a corticotropin-releasing factor in chronically catheterized fetal lambs. Journal of Clinical Investigation 198779 984-988. (doi:10.1172/JCI112910)

47 Luger A, Calogero AE, Kalogeras K, Gallucci WT, Gold PW, Loriaux DL $\&$ Chrousos GP. Interaction of epidermal growth factor with the hypothalamic-pituitary-adrenal axis: potential physiologic relevance. Journal of Clinical Endocrinology and Metabolism 198866 334-337. (doi:10.1210/jcem-66-2-334)
48 Childs GV, Patterson J, Unabia G, Rougeau D \& Wu P. Epidermal growth factor enhances ACTH secretion and expression of POMC mRNA by corticotropes in mixed and enriched cultures. Molecular and Cellular Neurosciences 19912 235-243. (doi:10.1016/10447431(91)90050-X)

49 Childs GV, Rougeau D \& Unabia G. Corticotropin-releasing hormone and epidermal growth factor: mitogens for anterior pituitary corticotropes. Endocrinology 1995136 1595-1602. (doi:10.1210/endo. 136.4.7895669)

50 Oomizu S, Honda J, Takeuchi S, Kakeya T, Masui T \& Takahashi S. Transforming growth factor- $\alpha$ stimulates proliferation of mammotrophs and corticotrophs in the mouse pituitary. Journal of Endocrinology 2000165 493-501. (doi:10.1677/joe.0.1650493)

51 Fukuoka H, Cooper O, Ben-Shlomo A, Mamelak A, Ren SG, Bruyette D $\&$ Melmed S. EGFR as a therapeutic target for human, canine, and mouse ACTH-secreting pituitary adenomas. Journal of Clinical Investigation 2011121 4712-4721. (doi:10.1172/JCI60417)

52 Onguru O, Scheithauer BW, Kovacs K, Vidal S, Jin L, Zhang S, Ruebel KH $\&$ Lloyd RV. Analysis of epidermal growth factor receptor and activated epidermal growth factor receptor expression in pituitary adenomas and carcinomas. Modern pathology 200417 772-780. (doi:10.1038/ modpathol.3800118)

53 Lidhar K, Korbonits M, Jordan S, Khalimova Z, Kaltsas G, Lu X, Clayton RN, Jenkins PJ, Monson JP, Besser GM et al. Low expression of the cell cycle inhibitor p27Kip1 in normal corticotroph cells, corticotroph tumors, and malignant pituitary tumors. Journal of Clinical Endocrinology and Metabolism 199984 3823-3830. (doi:10.1210/ jcem.84.10.6066)

54 Roussel-Gervais A, Bilodeau S, Vallette S, Berthelet F, Lacroix A, Figarella-Branger D, Brue T \& Drouin J. Cooperation between cyclin E and p27(Kip1) in pituitary tumorigenesis. Molecular Endocrinology 2010 24 1835-1845. (doi:10.1210/me.2010-0091)

55 Ciechanover A. The ubiquitin-proteasome proteolytic pathway. Cell 199479 13-21. (doi:10.1016/0092-8674(94)90396-4)

56 Gao T, Liu Z, Wang Y, Cheng H, Yang Q, Guo A, Ren J \& Xue Y. UUCD: a family-based database of ubiquitin and ubiquitin-like conjugation. Nucleic Acids Research 201341 D445-D451. (doi:10.1093/nar/gks1103)

57 Kulathu Y \& Komander D. Atypical ubiquitylation - the unexplored world of polyubiquitin beyond Lys48 and Lys63 linkages. Nature Reviews. Molecular Cell Biology 201213 508-523. (doi:10.1038/ nrm3394)

58 Reyes-Turcu FE, Ventii KH \& Wilkinson KD. Regulation and cellular roles of ubiquitin-specific deubiquitinating enzymes. Annual Review of Biochemistry 200978 363-397. (doi:10.1146/annurev.biochem.78. 082307.091526)

59 Komander D, Clague MJ \& Urbé S. Breaking the chains: structure and function of the deubiquitinases. Nature Reviews. Molecular Cell Biology 200910 550-563. (doi:10.1038/nrm2731)

60 Clague MJ, Liu H \& Urbé S. Governance of endocytic trafficking and signaling by reversible ubiquitylation. Developmental Cell 201223 457-467. (doi:10.1016/j.devcel.2012.08.011)

61 Haglund K \& Dikic I. The role of ubiquitylation in receptor endocytosis and endosomal sorting. Journal of Cell Science 2012125 265-275. (doi:10.1242/jcs.091280)

62 Tanno H \& Komada M. The ubiquitin code and its decoding machinery in the endocytic pathway. Journal of Biochemistry 2013153 497-504. (doi:10.1093/jb/mvt028)

63 Sorkin A \& Waters CM. Endocytosis of growth factor receptors. BioEssays: News and Reviews in Molecular, Cellular and Developmental Biology 199315 375-382. (doi:10.1002/bies.950150603)

64 Levkowitz G, Waterman H, Zamir E, Kam Z, Oved S, Langdon WY, Beguinot L, Geiger B \& Yarden Y. c-Cbl/Sli-1 regulates endocytic sorting and ubiquitination of the epidermal growth factor receptor. Genes and Development 199812 3663-3674. (doi:10.1101/gad.12.23.3663)

65 Levkowitz G, Waterman H, Ettenberg SA, Katz M, Tsygankov AY, Alroy I, Lavi S, Iwai K, Reiss Y, Ciechanover A et al. Ubiquitin ligase 
activity and tyrosine phosphorylation underlie suppression of growth factor signaling by c-Cbl/Sli-1. Molecular Cell 19994 1029-1040. (doi:10.1016/S1097-2765(00)80231-2)

66 Niendorf S, Oksche A, Kisser A, Löhler J, Prinz M, Schorle H, Feller S, Lewitzky M, Horak I \& Knobeloch KP. Essential role of ubiquitinspecific protease 8 for receptor tyrosine kinase stability and endocytic trafficking in vivo. Molecular and Cellular Biology 200727 5029-5039. (doi:10.1128/MCB.01566-06)

67 Morrison DK. The 14-3-3 proteins: integrators of diverse signaling cues that impact cell fate and cancer development. Trends in Cell Biology 200919 16-23. (doi:10.1016/j.tcb.2008.10.003)

68 Mizuno E, Kitamura N \& Komada M. 14-3-3-dependent inhibition of the deubiquitinating activity of UBPY and its cancellation in the M phase. Experimental Cell Research 2007313 3624-3634. (doi:10.1016/ j.yexcr.2007.07.028)

69 Welz T, Wellbourne-Wood J \& Kerkhoff E. Orchestration of cell surface proteins by Rab11. Trends in Cell Biology 201424 407-415. (doi:10.1016/j.tcb.2014.02.004)

70 Turjanski AG, Vaqué JP \& Gutkind JS. MAP kinases and the control of nuclear events. Oncogene 200726 3240-3253. (doi:10.1038/sj.onc.1210415)
71 Johnson LK, Vlodavsky I, Baxter JD \& Gospodarowicz D. Nuclear accumulation of epidermal growth factor in cultured rat pituitary cells. Nature 1980287 340-343. (doi:10.1038/287340a0)

72 Lin SY, Makino K, Xia W, Matin A, Wen Y, Kwong KY, Bourguignon L \& Hung MC. Nuclear localization of EGF receptor and its potential new role as a transcription factor. Nature Cell Biology 20013 802-808. (doi:10.1038/ncb0901-802)

73 Roskoski R Jr. The ErbB/HER family of protein-tyrosine kinases and cancer. Pharmacological Research 201479 34-74. (doi:10.1016/j.phrs. 2013.11.002)

74 Bilodeau S, Vallette-Kasic S, Gauthier Y, Figarella-Branger D, Brue T, Berthelet F, Lacroix A, Batista D, Stratakis C, Hanson J et al. Role of Brg1 and HDAC2 in GR trans-repression of the pituitary POMC gene and misexpression in Cushing disease. Genes and Development 200620 2871-2886. (doi:10.1101/gad.1444606)

75 Riebold M, Kozany C, Freiburger L, Sattler M, Buchfelder M, Hausch F, Stalla GK \& Paez-Pereda M. A C-terminal HSP90 inhibitor restores glucocorticoid sensitivity and relieves a mouse allograft model of Cushing disease. Nature Medicine 201521 276-280. (doi:10.1038/ nm.3776)

Received 22 March 2015

Revised version received 4 May 2015

Accepted 26 May 2015 